\title{
Increased Extracellular Amyloid Deposition and Neurodegeneration in Human Amyloid Precursor Protein Transgenic Mice Deficient in Receptor-Associated Protein
}

\author{
Emily Van Uden, ${ }^{1}$ Margaret Mallory, ${ }^{1}$ Isaac Veinbergs, ${ }^{1}$ Michael Alford, ${ }^{1}$ Edward Rockenstein, ${ }^{1}$ and \\ Eliezer Masliah ${ }^{1,2}$

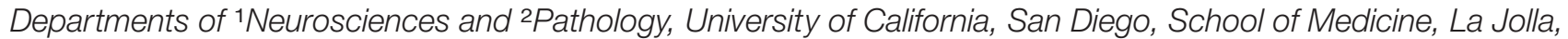 \\ California 92093-0624
}

\begin{abstract}
The low-density lipoprotein receptor-related protein (LRP) is an abundant neuronal cell surface receptor that regulates amyloid $\beta$-protein $(A \beta)$ trafficking into the cell. Specifically, LRP binds secreted $A \beta$ complexes and mediates its degradation. Previously, we have shown in vitro that the uptake of $A \beta$ mediated by LRP is protective and that blocking this receptor significantly enhances neurotoxicity. To further characterize the effects of LRP and other lipoprotein receptors on $A \beta$ deposition, an in vivo model of decreased LRP expression, receptor-associated protein (RAP)-deficient (RAP-/-) mice was crossed with human amyloid protein precursor transgenic (hAPP tg) mice, and plaque formation and neurodegeneration were analyzed. We
\end{abstract}

The low-density lipoprotein receptor (LDL-R) family consists of cell surface receptors that internalize extracellular ligands for lysosomal degradation (Hussain et al., 1999; Herz and Strickland, 2001) and includes the LDL-R, apopoliprotein E receptor-2 (apoER2), very low-density lipoprotein receptor (VLDL-R), low-density lipoprotein receptor-related protein (LRP), and Megalin/gp330 (Herz and Beffert, 2000; Herz, 2001a). Altered functioning of members of this family has been proposed recently to play an important role in Alzheimer's disease (AD) (Herz and Beffert, 2000) because they bind apoE (Herz and Beffert, 2000) and are expressed by glial cells surrounding the plaques (Christie et al., 1996), in which they modulate the inflammatory response to amyloid (LaDu et al., 2000), and genetic polymorphisms are probably linked to increased susceptibility to AD (Helbecque et al., 2001). Among them, LRP might play an especially important role in AD pathogenesis because ligands of this receptor, such as amyloid precursor protein (APP) (Kounnas et al., 1995), apoE (Herz and Beffert, 2000), and $\alpha 2$-macroglobulin ( $\alpha 2 \mathrm{M})$ (Borth, 1992), are genetic risk factors for AD (Goate et al., 1991; Saunders et al., 1993; Blacker et al., 1998) and are found in the amyloid plaques (Rebeck et al., 1995). Furthermore, levels of LRP decrease with age, and a polymorphism in exon 3 of the LRP gene (C776T) has been associated with increased risk for late onset AD (Kang et al., 1997, 2000). Moreover, LRP and other lipopro-

\footnotetext{
Received April 19, 2002; revised July 23, 2002; accepted Aug. 14, 2002.

This work was supported by National Institutes of Health Grants AG5131, AG10689, and AG18440 and by a grant from the M. J. Fox Foundation for Parkinson's Research. We thank Dr. Lennart Mucke for his helpful comments and providing the hAPP tg mice for these experiments.

Correspondence should be addressed to Dr. E. Masliah, Department of Neurosciences, University of California, San Diego, La Jolla, CA 92093-0624. E-mail: emasliah@ucsd.edu.

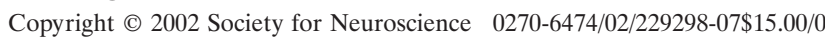

found that, although the age of onset for plaque formation was the same in hAPP $\mathrm{tg}$ and hAPP $\operatorname{tg} / \mathrm{RAP}-/-$ mice, the amount of amyloid deposited doubled in the hAPP tg/RAP-/- background. Moreover, these mice displayed increased neuronal damage and astrogliosis. Together, these results further support the contention that LRP and other lipoprotein receptors might be neuroprotective against $A \beta$ toxicity and that this receptor might play an integral role in $A \beta$ clearance.

Key words: amyloid $\beta$ protein; amyloid precursor protein; apopoliprotein E; low-density lipoprotein receptor; receptorassociated protein; transgenic mice

tein receptors might play a role in AD by influencing the clearance of amyloid $\beta$-protein $(\mathrm{A} \beta)$ and the processing of APP, both central to the pathogenesis of AD (Trommsdorff et al., 1998; Ulery et al., 2000; Rebeck et al., 2001). A $\beta$ is one of the proteolytic products of APP metabolism generated from the concerted cleavage at the $\mathrm{N}$ - and $\mathrm{C}$-terminal site of the molecule by $\beta$ and $\gamma$ secretase, respectively (Checler, 1995; Selkoe et al., 1996; Sinha et al., 2000; Huse and Doms, 2001). The mechanisms by which LRP and other lipoprotein receptors might regulate APP metabolism are under intense scrutiny (Kounnas et al., 1995). However, most recent studies point to a central role for LRP. For example, although binding of Kunitz protease inhibitor (KPI) containing isoforms of APP (APP751 and APP770) to LRP results in increased $\mathrm{A} \beta$ production, binding of $\mathrm{A} \beta$ to LRP ligands, such as $\alpha 2 \mathrm{M}$ or apoE, contributes to reduced $\mathrm{A} \beta$ levels (Qiu et al., 1999; Rebeck et al., 2001). Furthermore, the C-terminal site of APP interacts with LRP via the adapter protein Fe65 (Trommsdorff et al., 1998; Kinoshita et al., 2001). This ectodomain interaction might alter the endocytic process responsible for $\mathrm{A} \beta$ generation. Thus, alterations on LRP and other lipoprotein receptor functioning might contribute to AD by modifying the processing of APP and the production and clearance of $\mathrm{A} \beta$ (Herz and Beffert, 2000).

To better understand the role of LRP and other lipoprotein receptors in AD and APP metabolism in vivo, transgenic (tg) mice overexpressing mutant human APP (hAPP) under the platelet-derived growth factor (PDGF) B chain promoter (Mucke et al., 2000b) were crossed with receptor-associated, proteindeficient (RAP-/-) (Van Uden et al., 1999a) mice, and plaque formation and levels of $\mathrm{A} \beta_{1-40}$ and $\mathrm{A} \beta_{1-42}$ were evaluated. For these experiments, RAP $-/-$ mice were selected because previous studies have shown that it is possible to reduce the levels of 
LRP and other lipoprotein receptors (Van Uden et al., 1999a; Veinbergs et al., 2001) by deleting the $R A P$ gene and because the homozygous LRP knock-out model is lethal (Willnow et al., 1995).

\section{MATERIALS AND METHODS}

Generation of transgenic mice. The generation of mice expressing hAPP from the PDGF promoter has been described previously (Mucke et al., $2000 \mathrm{~b})$. The hAPP tg line J9 selected for this study expresses an alternatively spliced minigene, $h A P P$, bearing the amyloidogenic $V 717 \mathrm{~F}$ and K670M/N671L mutations that have been linked to familial AD (Games et al., 1995). The line has been maintained by crossing heterozygous transgenic mice with nontransgenic $(\mathrm{C} 57 \mathrm{BL} / 6 \mathrm{~J} \times \mathrm{DBA} / 2) \mathrm{F} 1$ breeders. The generation (Willnow et al., 1995) and further characterization (Van Uden et al., 1999a; Veinbergs et al., 2001) of RAP-/- mice on a C57BL/6 $\times 129$ hybrid background have also been described. Compared with mice expressing endogenous $\mathrm{RAP}(\mathrm{RAP}+/+), \mathrm{RAP}-/-$ mice were selected because previous studies have shown that it is possible to reduce the levels of LRP and other lipoprotein receptors by $75 \%$ by deleting the $R A P$ gene (Willnow et al., 1995; Veinbergs et al., 2001) and because the homozygous LRP knock-out model is lethal (Willnow et al., 1995). Interestingly, although RAP-/- mice do not exhibit any gross alterations (Willnow et al., 1995; Umans et al., 1999; Van Uden et al., 1999a), they are difficult to breed (Umans et al., 1999) and display significant age-related alterations in somatostatin-expressing neurons, accompanied by performance deficits in the water maze (Van Uden et al., 1999a). Deletion of the $R A P$ gene results in reduced trafficking of LRP and other lipoprotein receptors to the plasma membrane because this $39 \mathrm{kDa}$ chaperone molecule $(\mathrm{Bu}, 2001)$ facilitates the trafficking of lipoprotein receptors to the membrane (Bu et al., 1995; Willnow et al., 1996). Heterozygous hAPP transgenic mice $(\mathrm{hAPP}+/-\operatorname{tg})$ were crossed with homozygous RAP knock-out ( $\mathrm{RAP}-/-$ ) mice, and the resulting offspring (hAPP $+/-\operatorname{tg} / \mathrm{RAP}+/-$ ) were intercrossed to obtain the genotypes used in this study. The resulting groups of littermates contained comparable random mixtures of the C57BL/6, DBA/2, and 129 strains. All mice used in this study were wild type for the mouse APP gene. Genomic DNA was extracted from tail biopsies and analyzed by PCR for the presence of the hAPP transgene (Mucke et al., 2000b) and the endogenous $R A P$ gene (Van Uden et al., 1999a).

Tissue processing. Mice were killed by transcardiac saline perfusion under anesthesia with chloral hydrate; brains were removed and divided sagitally. The right hemibrain was snap frozen and stored at $-70^{\circ} \mathrm{C}$ for RNA or protein analysis (Van Uden et al., 1999b), and the left was drop fixed in phosphate-buffered $4 \%$ paraformaldehyde at $4^{\circ} \mathrm{C}$ for $48 \mathrm{hr}$ and serially sectioned sagitally at $40 \mu \mathrm{m}$ with the Vibratome 2000 (Leica, Deerfield, IL) for neuropathological analysis (Van Uden et al., 1999a; Veinbergs et al., 2001).

$R N A$ extraction and analysis. Total RNA from snap-frozen hemibrains or dissected brain regions (neocortex and hippocampus) was isolated with Tri-reagent (Molecular Research Center, Cincinnati, $\mathrm{OH}$ ) and stored in Formazol buffer (Molecular Research Center) at $-20^{\circ} \mathrm{C}$. Total RNA (10 $\mu \mathrm{g} / \mathrm{sample})$ was analyzed by solution hybridization RNase protection assay as described previously (Van Uden et al., 1999b). Samples were separated on 5\% acrylamide-8 M urea Tris-borate-EDTA gels, and dried gels were exposed to Kodak XAR film (Eastman Kodak, Rochester, NY). mRNA levels were quantitated from PhosphorImager readings of probe-specific signals corrected for RNA content-loading errors by normalization to $\beta$-actin signals. The following ${ }^{32} \mathrm{P}$-labeled antisense riboprobes were used to identify specific mRNAs [protected nucleotides (nt) (GenBank accession number)]: hAPP [nt 780-1009 (accession number NM 000484) of hAPP exon 6], murine APP (mAPP) [nt 702-881 (accession number X59379) of mAPP exon5], and $m \beta$-actin [nt 480-565 (accession number X03672) of mouse $\beta$-actin mRNA].

Western blot analysis. Levels of RAP, LRP, LDL-R, and hAPP expression in the brain were assessed by Western blot, as described previously (Van Uden et al., 1999b; Veinbergs et al., 2001). Briefly, aliquots from cytosolic and particulate fractions assayed by the Lowry method were loaded (15 $\mu \mathrm{g} /$ lane) into SDS-PAGE gels $(10 \%)$ and then blotted onto nitrocellulose paper. Blots were incubated with rabbit polyclonal antibodies against RAP $(1: 20,000)$ and LRP $(1: 1000$, both courtesy of Dr. Robert Orlando, University of New Mexico, Alburquerque, NM) and the mouse monoclonal antibodies against LDL-R (Calbiochem, San Diego, CA) (1:1000) and hAPP (8E5; 1:10,000; courtesy of Elan Pharmaceuticals, South San Francisco, CA), followed by ${ }^{125}$ I-protein A. Finally, blots were exposed to PhosphorImager (Molecular Dynamics, Sunnyvale, CA) screens and analyzed with ImageQuant software (Molecular Dynamics).

Detection of $A \beta$ deposits. Vibratome sections were incubated overnight at $4{ }^{\circ} \mathrm{C}$ with the biotinylated mouse monoclonal antibody 3D6 (1:600; courtesy of Elan Pharmaceuticals), which specifically recognizes A $\beta$. Binding of primary antibody was detected with the Vector Laboratories (Burlingame, CA) Elite kit using diaminobenzidine (DAB) $-\mathrm{H}_{2} \mathrm{O}_{2}$ for development. Sections were counterstained with $1 \%$ hematoxylin and examined with a Vanox light microscope (Olympus Optical, Tokyo, Japan) using a $2.5 \times$ objective. The percentage area of the hippocampus covered by 3D6-immunoreactive (IR) material ("plaque load") was determined with the Quantimet 570C as described previously (Mucke et al., 2000a,b). Three immunolabeled sections were analyzed per mouse, and the average of the individual measurements was used to calculate group means.

Some sections were double immunolabeled with the rabbit polyclonal antibody against A $\beta$ [R1280; 1:500; courtesy of Dr. Dennis Selkoe (Brigham and Women's Hospital, Harvard University, Boston, MA)] (Joachim et al., 1991) and either phosphorylated neurofilaments (SMI 312; 1:1000; Sternberger Monoclonals, Baltimore, MD) or phosphorylated tau (AT8; 1:100; Innogenetics, Norcross, GA), as described previously (Mucke et al., 2000b). Sections were analyzed with the laser scanning confocal microscope (LSCM), and serial optical z-sections $(0.2$ $\mu \mathrm{m}$ thick) of the double-immunolabeled neuritic plaques were collected from each region using the dual-channel imaging capability of the confocal microscope (Mucke et al., 2000b). The Texas Red channel collected the R1280-immunolabeled amyloid deposits, and the fluorescein isothiocyanate (FITC) channel collected the corresponding images of the SMI312- or AT8-immunolabeled elements in the plaques.

Determinations of $A \beta$ by ELISA. Briefly, as described previously (Rockenstein et al., 2001), brain samples of human or mouse cortex were homogenized in an ice-cold buffer containing $5 \mathrm{~m}$ guanidine- $\mathrm{HCl}$ and PBS containing $1 \times$ protease inhibitor cocktail (Calbiochem), $\mathrm{pH}$ 8.0. The homogenate was then mixed for 3-4 hr at room temperature and centrifuged at $16,000 \times g$ for $20 \mathrm{~min}$ at $4^{\circ} \mathrm{C}$. The supernatant was diluted 10 -fold in Dulbecco's PBS, pH 7.4, containing 5\% bovine serum albumin and $0.03 \%$ Tween 20. Quantification of $A \beta_{1-40}$ and $A \beta_{1-42}$ in the diluted brain homogenates was performed with a commercially available sandwich-type ELISA for $\mathrm{A} \beta_{1-40}$ and $\mathrm{A} \beta_{1-42}$ (Biosource, Camarillo, CA).

Analysis of neurodegeneration. To determine whether the alterations in APP metabolism in the hAPP tg/RAP-/- were associated with increased neurodegeneration, vibratome brain sections were immunostained with the mouse monoclonal antibodies against glial fibrillary acidic protein (GFAP) (1:500; marker of astrogliosis in response to neuronal injury; Chemicon, Temecula, CA) or microtubule-associated proteins (MAP2) (1:10; marker of dendrites; Chemicon) as described previously (Hsia et al., 1999; Rockenstein et al., 2001). For GFAP, sections were processed by standard immunoperoxidase techniques using the avidin-biotin complex Elite kit (Vector Laboratories) with DAB. For each case, sections were immunolabeled in duplicate and analyzed with the Quantimet $570 \mathrm{C}$ to determine the levels of GFAP immunoreactivity (corrected optical density) in the neocortex and hippocampus.

For anti-MAP2 (1:10; Chemicon), sections were incubated overnight, followed by incubation with FITC-conjugated horse anti-mouse IgG (1:75; Vector Laboratories). Sections were then transferred to SuperFrost slides (Fisher Scientific, Houston, TX), mounted under glass coverslips with anti-fading medium (Vector Laboratories), and imaged with the LSCM, as described previously (Mucke et al., 2000b). For each experiment, we first determined the linear range of the fluorescence intensity of immunoreactive dendrites in non-tg control sections. This setting was then used to collect all images analyzed in the same experiment. For each mouse, 12 confocal images (four per section) of the neocortex and caudate-putamen, each covering an area of $7282 \mu \mathrm{m}^{2}$, were obtained. Digitized images were transferred to a Macintosh computer (Apple Computers, Cupertino, CA) and analyzed with NIH Image 1.43 software. The area occupied by MAP2-IR dendrites was quantified and expressed as a percentage of the total image area (Mucke et al., $2000 \mathrm{~b}$ ). This method of quantifying MAP2-IR dendrites has been used extensively to assess neurodegenerative alterations in diverse experimental models and in diseased human brains. It has also been validated previously by comparisons with quantitative immunoblots and modifications of the stereological "dissector" approach. To ensure objective assessments and reliability of results, all sections in any given experiment were blind coded and processed in parallel. 
A

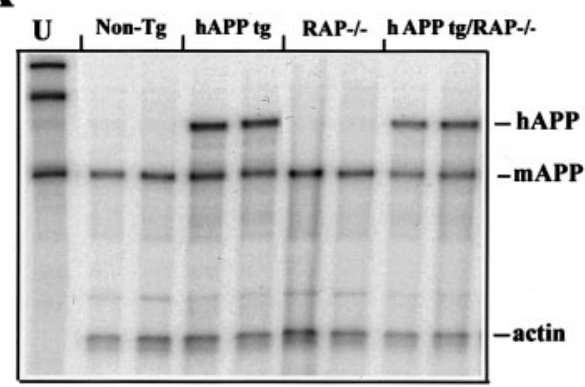

C

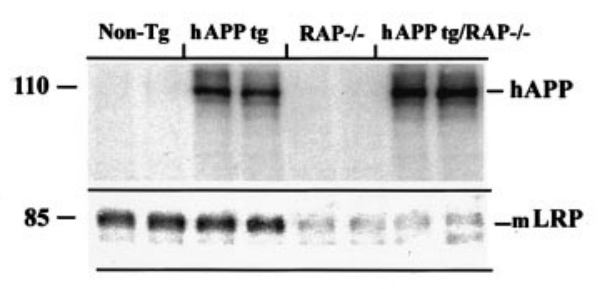

B

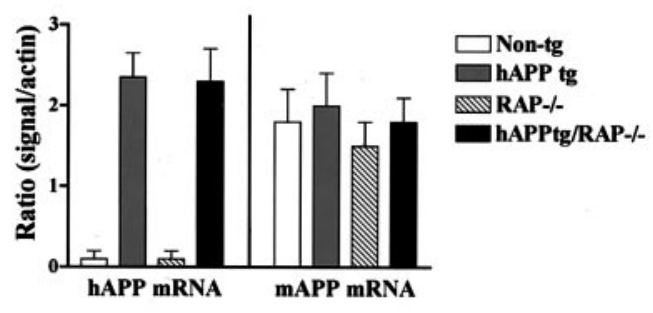

D

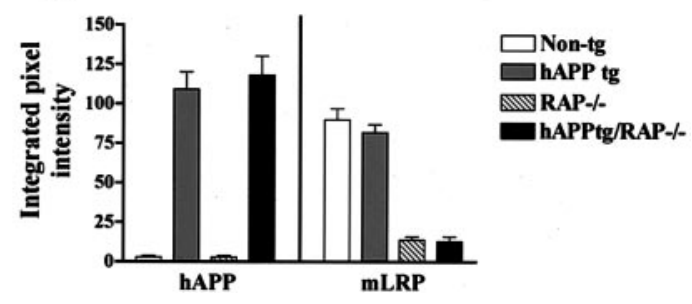

Figure 1. Characterization of APP and LRP expression in hAPP tg/RAP-/mice. $A$, Ribonuclease protection assay. A total of four mice per group was analyzed. Representative autoradiogram for mAPP and hAPP is shown. The leftmost lane represents the undigested $(U)$ radiolabeled probes; the other lanes contain the same riboprobes plus brain RNA samples digested with RNases. Protected mRNAs are indicated on the right. The hAPP, mAPP, and actin mRNA bands were detected as fragments of 230, 180, and $85 \mathrm{nt}$, respectively. $B$, Analysis of levels of hAPP and mAPP mRNA expression in tg mice; results are expressed as a ratio of APP to actin. Error bars are mean \pm SEM. $C$, Western blot analysis with antibodies against hAPP and LRP. The hAPP-specific antibody identified a broad band at an approximate molecular weight (MW) of $110 \mathrm{kDa}$. The specific antibody against the $\mathrm{C}$-terminal region of LRP detected a band at an approximate $\mathrm{MW}$ of $85 \mathrm{kDa}$. $D$, Analysis of hAPP and LRP immunoreactivity; results are expressed as integrated pixel intensity. Error bars are mean \pm SEM.
Statistical analyses. For all studies described, mice were coded to ensure objective assessment, and codes were not broken until the analysis was complete. Statistical analyses were performed with the StatView 5.0 program (SAS Institute, Cary, NC). Differences among means were assessed by one-way ANOVA followed, as indicated, by Dunnett's or Tukey-Kramer post hoc tests. Correlation studies were performed by simple regression analysis. The null hypothesis was rejected at the 0.05 level.

\section{RESULTS}

\section{Generation of hAPP tg mice lacking murine RAP}

To study in vivo the influence of LRP and other lipoprotein receptors on amyloid deposition and other AD-related neuropathology, we bred RAP $-/-$ mice with hAPP tg mice. These crosses yielded the following groups of mice: (1) non-tg expressing the endogenous mRAP (RAP $+/+)(n=15,10$ months; $n=14,18$ months), (2) non-tg lacking endogenous mRAP (RAP-/-) $(n=$ 8, 10 months; $n=8,18$ months), (3) hAPP tg expressing both copies of the endogenous mRAP ( $n=15,10$ months; $n=14,18$ months), and (4) hAPP tg lacking endogenous mRAP ( $n=5,10$ months; $n=5,18$ months) (hAPP $\operatorname{tg} / \mathrm{RAP}-/-$ ). Levels of hAPP expression were comparable in both groups of tg mice lacking or expressing endogenous RAP (Fig. $1 A, B$ ). Furthermore, levels of mAPP expression were unchanged among the four groups (Fig. $1 A, B)$. Western blot analysis confirmed that hAPP expression levels were comparable in both groups of $\mathrm{tg}$ mice lacking or expressing endogenous RAP (Fig. 1C,D). Moreover, in both hAPP tg and non-tg mice bred on the RAP-/- background, levels of LRP immunoreactivity were similarly reduced by $\sim 80 \%$ (Fig. 1C,D). LDL-R immunoreactivity levels were reduced in both RAP $-/-$ groups by $\sim 40 \%$ (data not shown). Patterns of hAPP immunoreactivity (Fig. $2 A-D$ ) were unchanged in mice expressing endogenous mRAP (Fig. $2 E, F$ ) compared with mice in which this chaperone protein was deleted (Fig. $2 G, H$ ). Consistent with the Western blot analysis, immunocytochemical analysis with an LRP antibody showed that, compared with non-tg and hAPP tg mice (Fig. 2I,J), mice bred on the RAP-/background display a similar reduction in levels and patterns of LRP immunoreactivity (Fig. $2 K, L$ ).
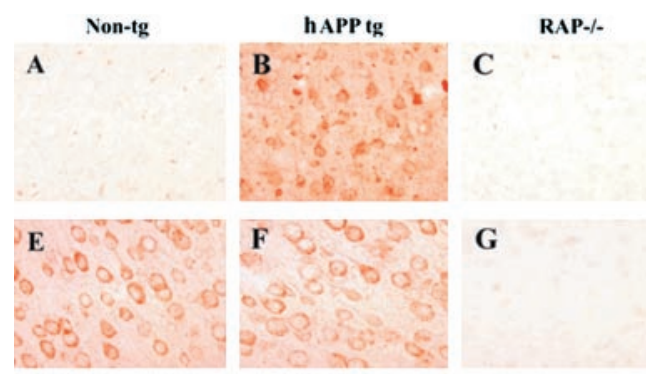

G
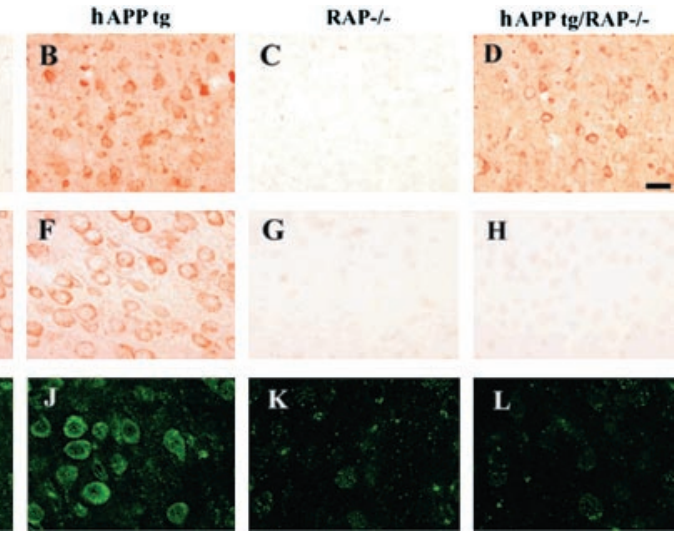

H
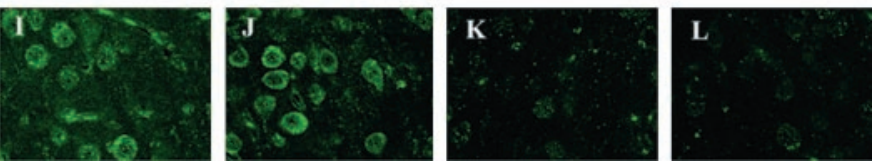

Figure 2. Immunocytochemical analysis of hAPP, RAP, and LRP expression in hAPP tg/RAP $-/-$ mice. $A-D$, hAPP immunoreactivity with the $8 \mathrm{E} 5$ monoclonal antibody; $E-H$, RAP immunoreactivity in the frontal cortex of 18 -month-old mice; $I-L$, LRP immunoreactivity in the frontal cortex of 18-month-old mice. $A$, No hAPP immunoreactivity was observed in non-tg mice. $B$, hAPP tg mice displayed immunostaining of a subset of pyramidal neurons in the neocortex. $C$, No hAPP immunoreactivity was observed in RAP-/- mice. $D$, hAPP $\operatorname{tg} / \mathrm{RAP}-/-\operatorname{tg}$ mice hAPPimmunoreactive pyramidal neurons in the neocortex. $E$, Non-tg; $F$, hAPP $\operatorname{tg}$ mice showed extensive immunostaining of pyramidal neurons in the neocortex. In the RAP $-/-(G)$ and hAPP tg/R $\mathrm{AP}-/-(H)$, no RAP immunoreactivity was observed. Non-tg $(I)$ and hAPP $\operatorname{tg}(J)$ mice showed extensive LRP immunostaining of pyramidal neurons in the neocortex. In the RAP $-/-(G)$ and hAPP $\operatorname{tg} / \mathrm{RAP}-/-(H)$, no LRP levels of LRP immunoreactivity were decreased. Scale bar, $25 \mu \mathrm{m}$.

\section{Increased $\mathbf{A} \boldsymbol{\beta}$ deposition in hAPP $\operatorname{tg} / \mathrm{RAP}-/-\operatorname{tg}$ mice}

Cerebral deposition of $\mathrm{A} \beta$ was compared in all four groups of mice at 10 and 18 months of age. No amyloid deposits were detected in non-tg controls (Fig. $3 A$ ) and in RAP-/- mice (Fig. $3 C$ ). In contrast, hAPP tg (Fig. $3 B, I, J)$ and hAPP tg/RAP-/mice (Fig. $3 D, H, L$ ) developed typical AD-like plaques at $\sim 10$ months of age, with progressive accumulation of plaques observed at 18 months of age (Fig. $4 A$ ). At both ages analyzed, 


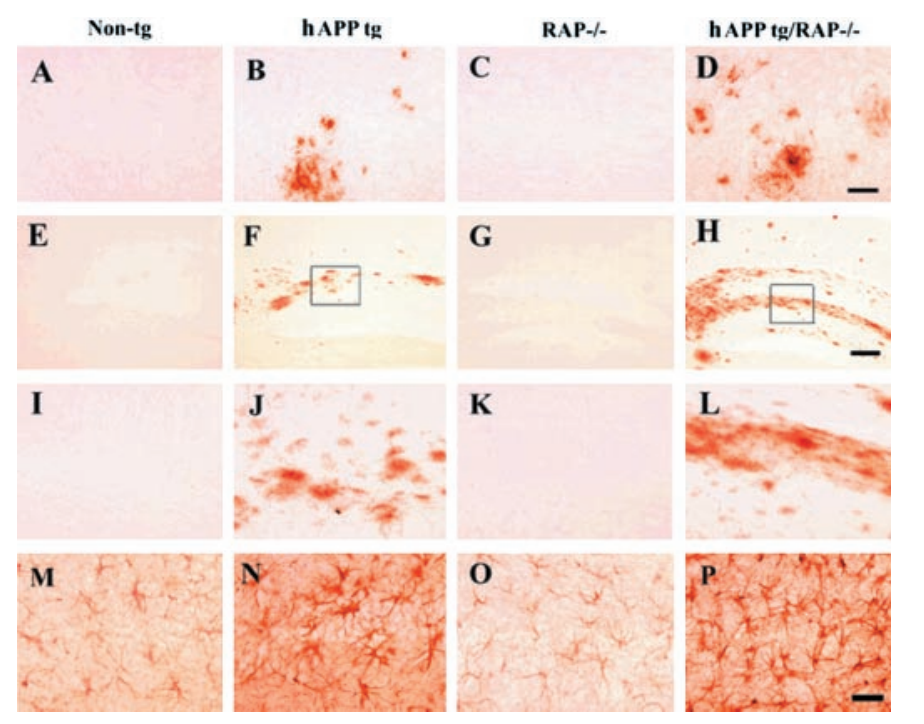

Figure 3. Patterns of $\mathrm{A} \beta$ immunoreactivity in hAPP $\operatorname{tg} / \mathrm{RAP}-/-. A-D$, $\mathrm{A} \beta$ immunoreactivity in the neocortex; $E-H$, low-power view $(60 \times)$ of the hippocampal dentate gyrus; $I-L$, higher-power view $(200 \times)$ of the dentate gyrus; $M, P$, GFAP immunoreactivity in the hippocampus. All images are from 18-month-old mice. $A$, No A $\beta$ deposits were observed in non-tg controls. $B$, Mature and diff use amyloid plaques in hAPP tg/RAP tg mice. $C$, No $\mathrm{A} \beta$ deposits were observed in $\mathrm{RAP}-/-$ mice. $D$, hAPP $\operatorname{tg} /$ $\mathrm{RAP}-/-$ mice displayed increased $\mathrm{A} \beta$ immunoreactive plaques. Scale bar, $20 \mu \mathrm{m}$. $E, I$, No A $\beta$ deposits were observed in the molecular layer of the dentate in non-tg controls. $F, J$, Abundant diffuse amyloid plaques in hAPP tg mice. $G, K$, No A $\beta$ deposits were observed in RAP-/- mice. $H$, $L$, hAPP $\operatorname{tg} / \mathrm{RAP}-/-$ mice displayed increased $\mathrm{A} \beta$ deposits in the molecular layer of the dentate. Scale bar, $60 \mu \mathrm{m}$. $M$, Mild astrogliosis in non-tg mice. $N$, Increased astroglial reaction in hAPP mice. $O$, Mild astroglial immunostaining in RAP-/- mice. $P$, Enhanced astroglial reaction in hAPP $\mathrm{tg} / \mathrm{RAP}-/-$ mice. Scale bar, $30 \mu \mathrm{m}$.

hAPP $\operatorname{tg} / \mathrm{RAP}-/-$ mice had a higher plaque load than hAPP $\operatorname{tg}$ mice (Fig. 4A). Compared with non-tg control (Fig. 3M) and RAP-/- (Fig. 3O) mice, hAPP tg (Fig. 3N) and hAPP tg/ RAP $-/-$ mice (Fig. $3 P$ ) developed reactive astrocytosis that was most prominent at 18 months of age (Fig. 4C).

The increased amyloid deposition in the hAPP $\mathrm{tg} / \mathrm{RAP}-/-$ mice could be because of effects of LRP and other lipoprotein receptors on the production, removal, or aggregation of A $\beta$. RAP expression did not affect cerebral hAPP mRNA or protein expression (Fig. $1 A, B$ ) or the characteristics of the plaques; however, the levels of $\mathrm{A} \beta_{1-42}$ in the hippocampus were elevated (Fig. $4 B$ ). Thus, the amyloidogenic effect of LRP and other lipoprotein receptors appears to result from decreased $A \beta$ clearance rather than from increased expression of the hAPP transgene or increased $\mathrm{A} \beta$ production.

Because loss of synaptic connections and dendritic damage is associated with cognitive deficits in AD (DeKosky and Scheff, 1990; Terry et al., 1991; Zhan et al., 1993; Dickson et al., 1995) and in hAPP tg mice (Hsia et al., 1999; Mucke et al., 2000b), we analyzed the levels MAP2 immunoreactivity (dendritic marker) in the hippocampus as an indicator of neurodegeneration. Compared with non-tg controls (Figs. $4 D, 5 A, E$ ), RAP-/- mice expression had normal levels of MAP2-IR dendrites (Figs. $4 D$, $5 C, G)$, indicating that decreased expression of LRP does not by itself affect the integrity of these structures. In contrast, hAPP tg mice had decreased levels of MAP2 immunoreactivity (Figs. $4 C$, $5 B, F)$, and the absence of RAP in these mice resulted in addi-
A
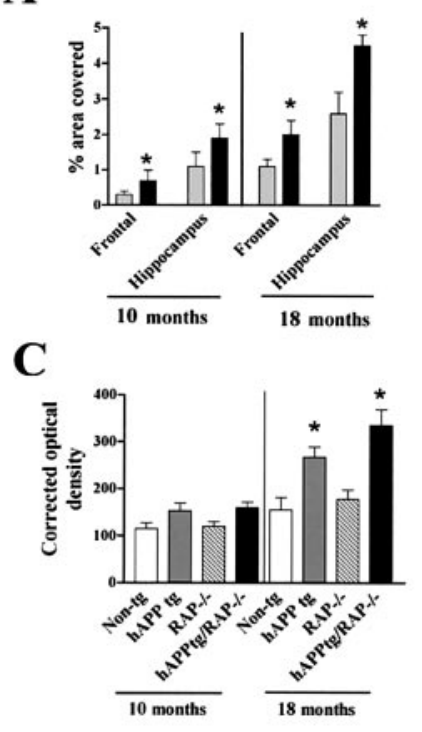

D
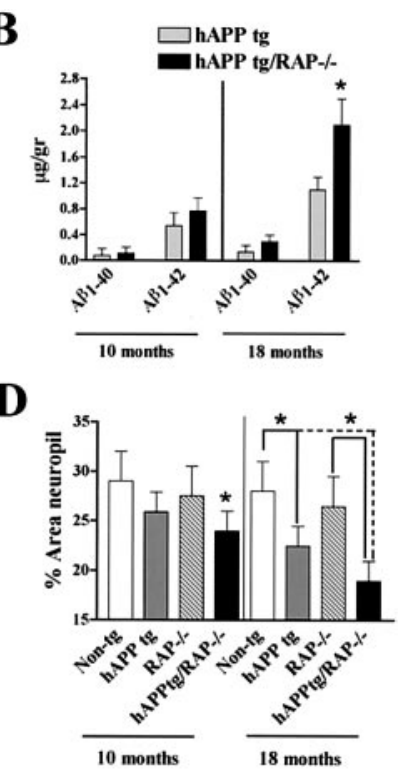

Figure 4. Quantitative analysis of amyloid production and neurodegeneration. $A$, Determination of percentage area of the neuropil occupied by $\mathrm{A} \beta$ immunoreactive deposits in the frontal cortex and hippocampus. $B$, Determination of $\mathrm{A} \beta$ levels in the hippocampus by ELISA in 10- and 18 -month-old mice. ${ }^{*} p<0.05$, different by two-tailed unpaired $t$ test when compared with hAPP tg mice. $C$, Densitometrical analysis of GFAP immunoreactivity in the hippocampus using the Quantimet 570C in 10and 18 -month-old mice. ${ }^{*} p<0.05$ different from non-tg control by one-way ANOVA post hoc Dunnet's test. $D$, Levels of MAP2-IR in the outer molecular layer of the dentate gyrus in 10- and 18-month-old mice. ${ }^{*} p<0.05$, different by one-way ANOVA post hoc Dunnet's test.
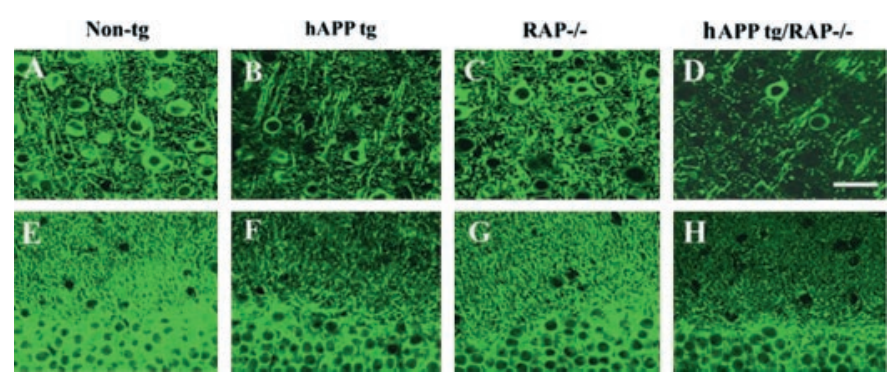

Figure 5. Patterns of dendritic degeneration in hAPP $\operatorname{tg} / \mathrm{RAP}-/-$. Sections from 18-month-old mice were immunolabeled with an antibody against MAP2 and imaged with the laser scanning confocal microscope. $A-D$, Neocortex; $E-H$, molecular layer of the hippocampal dentate gyrus. Scale bar, $20 \mu \mathrm{m}$.

tional decreases in the levels of MAP2 immunoreactivity (Figs. $4 C, 5 D, H)$.

\section{DISCUSSION}

The present study showed that decreased expression of LRP and other lipoprotein receptors resulted in increased amyloid deposition and neurodegeneration in hAPP $\operatorname{tg} / \mathrm{RAP}-/-$ mice. These results are consistent with previous studies showing that, in AD, amyloid deposition correlates with decreased LRP activity and supports the possibility that LRP might regulate $\mathrm{A} \beta$ clearance (Kang et al., 2000). Because previous studies have proposed that LRP might be centrally involved in the pathogenesis of AD (Herz and Beffert, 2000; Ulery et al., 2000) and LRP might be the main receptor responsible for A $\beta$ endocytosis (Narita et al., 1997b; Qiu et al., 1999), we hypothesized that the alterations observed in the 
hAPPtg/RAP-/- mice were probably most closely associated with altered functioning of LRP. Nevertheless, in addition to LRP, it is important to note that RAP also regulates the trafficking of other lipoprotein receptors, such as LDL-R, VLDL-R, and apoER2, albeit to a lesser extent (Herz et al., 1991; Bu, 1998, 2001). Thus, we cannot completely rule out the possibility that decreased expression of other receptors in the $\mathrm{RAP}-/-$ mice might also play a role increasing $A \beta$ deposition. However, it is worth noting that, in the RAP $-/-$ mice, LRP levels are reduced by $75-80 \%$, whereas levels of LDL-R and VLDL-R are reduced by $40-50 \%$ (Veinbergs et al., 2001). In addition, LRP appears to be the main lipoprotein receptor responsible for $\mathrm{A} \beta$ clearance (Narita et al., 1997b; Qiu et al., 1999), suggesting that, in the hAPP $\operatorname{tg} / \mathrm{RAP}-/-$ mice, the effects of other RAP-dependent receptors on $A \beta$ deposition might be less critical. However, future studies crossing hAPPtg mice with VLDL-R-/-, apoER2 -/-, or LDL-R-/- mice will be necessary to investigate this possibility.

Increased $\mathrm{A} \beta$ deposition in the hAPP $\operatorname{tg} / \mathrm{RAP}-/-$ model could be the result of increased $A \beta$ production or decreased $A \beta$ clearance by lipoprotein receptors. Increased $\mathrm{A} \beta$ production could result from increased hAPP synthesis or cleavage by $\beta$ and $\gamma$ secretases. However, because hAPP levels were not affected in the hAPP $\operatorname{tg} / \mathrm{RAP}-/-$, we concluded that the most likely cause for the increased $A \beta$ deposition could be a decrease in $\mathrm{A} \beta$ clearance by lipoprotein receptors. This is supported by studies showing that $\mathrm{A} \beta 40$ and $\mathrm{A} \beta 42$ bound to $\alpha 2 \mathrm{M}$ is cleared by LRP for subsequent degradation (Kang et al., 2000), and blocking LRP with RAP significantly decreased $\alpha 2 \mathrm{M}$-dependent A $\beta$ clearance in primary neuronal cultures and glial cells (Narita et al., 1997a; Fabrizi et al., 1999; Qiu et al., 1999). Furthermore, A $\beta$ binding to other LRP ligands, such as apoE, also contributes to reduced $\mathrm{A} \beta$ levels (Kang et al., 2000; Shibata et al., 2000; Herz and Strickland, 2001). Alternatively, reduced LRP levels may promote increased amyloid deposition in hAPP $\mathrm{tg} / \mathrm{RAP}-/-$ mice by impeding the clearance of apoE, $\alpha 2 \mathrm{M}$, and lactoferrin because all of these LRP ligands also sequester $\mathrm{A} \beta$ and mediate its clearance (Narita et al., 1997a; Yang et al., 1999; Kang et al., 2000). However, this possibility is less likely because altered expression of apoE in crosses between hAPP tg and apoE-deficient (Bales et al., 1997) or apoE tg (Irizarry et al., 2000) mice results in delayed amyloid deposition and redistribution of $\mathrm{A} \beta$ in the hippocampus that differs considerably with our observations in the hAPP $\operatorname{tg} / \mathrm{RAP}-/-$ mice.

Other receptors involved in $\mathrm{A} \beta$ clearance include the receptor for advanced glycation end products (RAGE), scavenger receptor type A (SR-A) (Paresce et al., 1996; Yan et al., 1996; El Khoury et al., 1998), and the G-protein-coupled receptor formyl peptide receptor like-1 (FPRL1) (Yazawa et al., 2001). Some interesting differences exist among these $\mathrm{A} \beta$ receptors. For example, LRP is found primarily in neurons, and $\mathrm{A} \beta$ binding is dependent on coupling to $\alpha 2 \mathrm{M}$, apoE, and apoJ (Herz, 2001b). In contrast, RAGE, SR-A, and FPRL1 are primarily found in macrophages, and $\mathrm{A} \beta$ binds to them as a free peptide (Shibata et al., 2000; Yazawa et al., 2001). Furthermore, RAGE and SR-A mediate brain endocytosis and transcytosis of $\mathrm{A} \beta$, whereas LRP mediates blood-brain barrier transport of plasma $\mathrm{A} \beta$ complexed to apoJ (Shibata et al., 2000). It is unclear how these receptors regulate $\mathrm{A} \beta$ levels in concert. However, no significant effects on $\mathrm{A} \beta$ deposition were observed in previous studies in which hAPP tg mice were crossed with SR-deficient mice (Huang et al., 1999). Together, these results suggest that in vivo lipoprotein receptor- mediated $\mathrm{A} \beta$ clearance is central to amyloid deposition. Additional studies in vivo in our models and others looking at circulating $\mathrm{A} \beta$ levels are warranted for additional clues into the clearance of $\mathrm{A} \beta$. Although our in vivo model results in the decreased expression of LRP and other lipoprotein receptors and recent studies in vitro and in AD brains suggests that decreased LRP levels are associated with decreased A $\beta$ clearance (Kang et al., 2000), the precise mechanisms by which LRP regulates $A \beta$ levels are complex and remain controversial. For example, in human neuroglioma (H4) cells, lack of LRP activity results in decreased $\mathrm{A} \beta$ production, whereas the presence of functional LRP is associated with increased production and secretion of $\mathrm{A} \beta$ (Ulery et al., 2000). Long-term treatment with RAP results in increased levels of both cell surface APP and secreted APP $\alpha$, along with decreased $\mathrm{A} \beta$ production (Ulery et al., 2000). These effects might be the result of direct interactions between APP and LRP, because fluorescence resonance energy transfer experiments have shown that there is a close opposition of the extracellular domains of KPI-containing APP and LRP that is RAP sensitive (Kinoshita et al., 2001). The association of LRP with forms of APP that contain the KPI domain alters APP processing, leading to altered $\mathrm{A} \beta$ production (Kinoshita et al., 2001). APP-LRP interactions in CHO cells have shown that decreased LRP activity by genetic deletion or by addition of exogenous RAP could result in decreased $\mathrm{A} \beta$ production from hAPP770transfected cells, and these ectodomain interactions alter the endocytic pathway (Kinoshita et al., 2001). Together, these studies suggest that LRP might influence $\mathrm{A} \beta$ metabolism by different mechanisms, including direct interactions with APP, as well as internalization and clearance of $\mathrm{A} \beta$ bound to $\alpha 2 \mathrm{M}$.

The present study also showed that decreased expression of LRP and other lipoprotein receptors resulted in greater synaptic damage in the hAPP $\operatorname{tg} / \mathrm{RAP}-/-$ mice. This is consistent with previous studies showing that LRP expressed by neurons has the capacity to signal and may be involved in long-term potentiation (LTP) and in regulating synaptic plasticity (Herz and Strickland, 2001). Perfusion of hippocampal slices with RAP reduced latephase LTP. In addition, RAP also blocked the enhancing effect of synaptic potentiation by exogenous application of the LRP ligand tissue type plasminogen activator (tPA) in hippocampal slices prepared from tPA knock-out mice, indicating that interactions between tPA and cell surface LRP are important for synaptic plasticity (Zhuo et al., 2000). Furthermore, RAP-/- mice display deficient somatostatin release and memory deficits in the water maze (Van Uden et al., 1999a) that are ameliorated by another LRP ligand, namely apoE (Veinbergs et al., 2001). In addition, previous studies have shown that, in the presence of $\alpha 2 \mathrm{M}$, LRP protects neural cell lines against the neurotoxic effects of A $\beta$ (Fabrizi et al., 1999; Van Uden et al., 1999b, 2000). These effects were blocked by exogenous administration of RAP and are dependent on calcium/calmodulin-dependent kinase 2 signaling (Van Uden et al., 2000). In hAPP tg mice, previous studies have shown that $\mathrm{A} \beta$ is synaptotoxic (Mucke et al., 2000b) and disrupts synaptic transmission independently of plaque formation (Hsia et al., 1999). Together, these studies suggest that LRP and its ligands might protect neurons against the neurotoxic effects of $\mathrm{A} \beta$ by facilitating $A \beta$ clearance.

In summary, the present study showed that decreased $\mathrm{A} \beta$ clearance in hAPP $\operatorname{tg} / \mathrm{RAP}-/-$ mice results in increased amyloid deposition and dendritic damage, supporting the contention that decreased expression of LRP and other lipoprotein receptors might play an important role in the pathogenesis of $\mathrm{AD}$ and that 
increasing LRP activity might represent a novel modality for treatment of AD.

\section{REFERENCES}

Bales K, Verina T, Dodel R, Du Y, Altstiel L, Bender M, Hyslop P, Johnstone E, Little S, Cummins D, Piccardo P, Ghetti B, Paul S (1997) Lack of apolipoprotein $\mathrm{E}$ dramatically reduces amyloid $\beta$-peptide deposition. Nat Genet 17:263-264.

Blacker D, Wilcox MA, Laird NM, Rodes L, Horvath SM, Go RC, Perry R, Watson Jr B, Bassett SS, McInnis MG, Albert MS, Hyman BT, Tanzi RE (1998) Alpha-2 macroglobulin is genetically associated with Alzheimer disease. Nat Genet 19:357-360.

Borth W (1992) Alpha 2-macroglobulin, a multifunctional binding protein with targeting characteristics. FASEB J 6:3345-3353.

Bu G (1998) Receptor-associated protein: a specialized chaperone and antagonist for members of the LDL receptor gene family. Curr Opin Lipidol 9:149-155.

Bu G (2001) The roles of receptor-associated protein (RAP) as a molecular chaperone for members of the LDL receptor family. Int Rev Cytol 209:79-116.

Bu G, Geuze H, Strous G, Schwartz A (1995) 39 kDa receptorassociated protein is an ER resident protein and molecular chaperone for LDL receptor-related protein. EMBO J 14:2269-2280.

Checler F (1995) Processing of the $\beta$-amyloid precursor protein and its regulation in Alzheimer's disease. J Neurochem 65:1431-1444.

Christie RH, Chung H, Rebeck GW, Strickland D, Hyman BT (1996) Expression of the very low-density lipoprotein receptor (VLDL-r), an apolipoprotein-E receptor, in the central nervous system and in Alzheimer's disease. J Neuropathol Exp Neurol 55:491-498.

DeKosky S, Scheff S (1990) Synapse loss in frontal cortex biopsies in Alzheimer's disease: correlation with cognitive severity. Ann Neurol 27:457-464.

Dickson D, Crystal H, Bevona C, Honer W, Vincent I, Davies P (1995) Correlations of synaptic and pathological markers with cognition of the elderly. Neurobiol Aging 16:285-304.

El Khoury J, Hickman SE, Thomas CA, Loike JD, Silverstein SC (1998) Microglia, scavenger receptors, and the pathogenesis of Alzheimer's disease. Neurobiol Aging 19:S81-S84.

Fabrizi C, Businaro R, Lauro G, Starace G, Fumagalli L (1999) Activated alpha2-microglobulin increases $\beta$-amyloid (25-35)-induced toxicity in LAN5 human neuroblastoma cells. Exp Neurol 155:252-259.

Games D, Adams D, Alessandrini R, Barbour R, Berthelette P, Blackwell C, Carr T, Clemes J, Donaldson T, Gillespie F, Guido T, Hagopian S, Johnson-Wood K, Khan K, Lee M, Leibowitz P, Lieberburg I, Little S, Masliah E, McConlogue L, et al. (1995) Alzheimer-type neuropathology in transgenic mice overexpressing $\mathrm{V} 717 \mathrm{~F} \beta$-amyloid precursor protein. Nature 373:523-527.

Goate A, Chartier-Harlin M-C, Mullan M, Brown J, Crawford F, Fidani L, Guiffra L, Haynes A, Irving N, James L, Mant R, Newton P, Rooke K, Roques P, Talbot C, Williamson R, Rossor M, Owen M, Hardy J (1991) Segregation of a missense mutation in the amyloid precursor protein gene with familial Alzheimer's disease. Nature 349:704-706.

Helbecque N, Berr C, Cottel D, Fromentin-David I, Sazdovitch V, Ricolfi F, Ducimetiere P, Di Menza C, Amouyel P (2001) VLDL receptor polymorphism, cognitive impairment, and dementia. Neurology 56:1183-1188.

Herz J (2001a) The LDL receptor gene family: (un)expected signal transducers in the brain. Neuron 29:571-581.

Herz J (2001b) Lipoprotein receptors: beacons to neurons? Trends Neurosci 24:193-195.

Herz J, Beffert U (2000) Apolipoprotein E receptors: linking brain development and Alzheimer's disease. Nat Rev Neurosci 1:51-58.

Herz J, Strickland DK (2001) LRP: a multifunctional scavenger and signaling receptor. J Clin Invest 108:779-784.

Herz J, Goldstein J, Strickland D, Ho Y, Brown M (1991) The 39-kDa protein modulates binding of ligands to low density lipoprotein receptor-related protein/alpha 2-macroglobulin receptor. J Biol Chem 266:21232-21238.

Hsia AY, Masliah E, McConlogue L, Yu G-Q, Tatsuno G, Hu K, Kholodenko D, Malenka RC, Nicoll RA, Mucke L (1999) Plaqueindependent disruption of neural circuits in Alzheimer's disease mouse models. Proc Natl Acad Sci USA 96:3228-3233.

Huang F, Buttini M, Wyss-Coray T, McConlogue L, Kodama T, Pitas RE, Mucke L (1999) Elimination of the class A scavenger receptor does not affect amyloid plaque formation or neurodegeneration in transgenic mice expressing human amyloid protein precursors. Am J Pathol 155:1741-1747.

Huse JT, Doms RW (2001) Neurotoxic traffic: uncovering the mechanics of amyloid production in Alzheimer's disease. Traffic 2:75-81.

Hussain MM, Strickland DK, Bakillah A (1999) The mammalian lowdensity lipoprotein receptor family. Annu Rev Nutr 19:141-172.

Irizarry MC, Cheung BS, Rebeck GW, Paul SM, Bales KR, Hyman BT (2000) Apolipoprotein E affects the amount, form, and anatomical distribution of amyloid beta-peptide deposition in homozygous APP(V717F) transgenic mice. Acta Neuropathol (Berl) 100:451-458.

Joachim C, Games D, Morris J, Ward P, Frenkel D, Selkoe D (1991) Antibodies to non-beta regions of the beta-amyloid precursor protein detect a subset of senile plaques. Am J Pathol 138:373-384.

Kang D, Saitoh T, Chen X, Xia Y, Masliah E, Hansen L, Thomas R, Thal L, Katzman R (1997) Genetic association of the low density lipoprotein receptor related protein gene (LRP), an apoE receptor, with late-onset Alzheimer's disease. Neurology 49:56-61.

Kang DE, Pietrzik CU, Baum L, Chevallier N, Merriam DE, Kounnas MZ, Wagner SL, Troncoso JC, Kawas CH, Katzman R, Koo EH (2000) Modulation of amyloid beta-protein clearance and Alzheimer's disease susceptibility by the LDL receptor-related protein pathway. J Clin Invest 106:1159-1166.

Kinoshita A, Whelan CM, Smith CJ, Mikhailenko I, Rebeck GW, Strickland DK, Hyman BT (2001) Demonstration by fluorescence resonance energy transfer of two sites of interaction between the lowdensity lipoprotein receptor-related protein and the amyloid precursor protein: role of the intracellular adapter protein Fe65. J Neurosci 21:8354-8361.

Kounnas M, Moir R, Rebeck G, Bush A, Argaves W, Tanzi R, Hyman B, Strickland D (1995) LDL receptor-related protein, a multif unctional apoE receptor, binds secreted $\beta$-amyloid precursor protein and mediates its degradation. Cell 82:331-340.

LaDu MJ, Shah JA, Reardon CA, Getz GS, Bu G, Hu J, Guo L, van Eldik LJ (2000) Apolipoprotein E receptors mediate the effects of betaamyloid on astrocyte cultures. J Biol Chem 275:33974-33980.

Mucke L, Yu GQ, McConlogue L, Rockenstein EM, Abraham CR, Masliah E (2000a) Astroglial expression of human alpha(1)antichymotrypsin enhances alzheimer-like pathology in amyloid protein precursor transgenic mice. Am J Pathol 157:2003-2010.

Mucke L, Masliah E, Yu G-Q, Mallory M, Rockenstein E, Tatsuno G, Hu K, Kholodenko D, Johnson-Wood K, McConlogue L (2000b) Highlevel neuronal expression of $\mathrm{A} \beta$ 1-42 in wild-type human amyloid protein precursor transgenic mice: synaptotoxicity without plaque formation. J Neurosci 20:4050-4058.

Narita M, Bu G, Holtzman D, Schwartz A (1997a) The low-density lipoprotein receptor-related protein, a multifunctional apolipoprotein E receptor, modulates hippocampal neurite development. J Neurochem 68:587-595

Narita M, Holtzman DM, Schwartz AL, Bu G (1997b) Alpha2macroglobulin complexes with and mediates the endocytosis of betaamyloid peptide via cell surface low-density lipoprotein receptorrelated protein. J Neurochem 69:1904-1911.

Paresce DM, Ghosh RN, Maxfield FR (1996) Microglial cells internalize aggregates of the Alzheimer's disease amyloid beta-protein via a scavenger receptor. Neuron 17:553-565.

Qiu Z, Strickland DK, Hyman BT, Rebeck GW (1999) Alpha2macroglobulin enhances the clearance of endogenous soluble betaamyloid peptide via low-density lipoprotein receptor-related protein in cortical neurons. J Neurochem 73:1393-1398.

Rebeck G, Harr S, Strickland D, Hyman B (1995) Multiple, diverse senile plaque-associated proteins are ligands of an apolipoprotein $\mathrm{E}$ receptor, the alpha 2-macroglobulin receptor/low-density-lipoprotein receptor-related protein. Ann Neurol 37:211-217.

Rebeck GW, Moir RD, Mui S, Strickland DK, Tanzi RE, Hyman BT (2001) Association of membrane-bound amyloid precursor protein APP with the apolipoprotein E receptor LRP. Mol Brain Res 87:238-245.

Rockenstein E, Mallory M, Mante M, Sisk A, Masliah E (2001) Early formation of mature amyloid-b proteins deposits in a mutant APP transgenic model depends on levels of Ab1-42. J Neurosci Res 66:573-582.

Saunders A, Strittmatter W, Schmechel D, St. George-Hyslop P, PericakVance M, Joo S, Rosi B, Gusella J, Crapper-MacLachlan D, Alberts M, Hulette C, Crain B, Goldgaber D, Roses A (1993) Association of apolipoprotein E allele E4 with late-onset familial and sporadic Alzheimer's disease. Neurology 43:1467-1472.

Selkoe DJ, Yamazaki T, Citron M, Podlisny MB, Koo EH, Teplow DB, Haass C (1996) The role of APP processing and trafficking pathways in the formation of amyloid beta-protein. Ann NY Acad Sci 777:57-64.

Shibata M, Yamada S, Kumar SR, Calero M, Bading J, Frangione B, Holtzman DM, Miller CA, Strickland DK, Ghiso J, Zlokovic BV (2000) Clearance of Alzheimer's amyloid-ss(1-40) peptide from brain by LDL receptor-related protein-1 at the blood-brain barrier. J Clin Invest 106:1489-1499.

Sinha S, Anderson J, John V, McConlogue L, Basi G, Thorsett E, Schenk D (2000) Recent advances in the understanding of the processing of APP to beta amyloid peptide. Ann NY Acad Sci 920:206-208.

Terry R, Masliah E, Salmon D, Butters N, DeTeresa R, Hill R, Hansen L, Katzman R (1991) Physical basis of cognitive alterations in Alzheimer disease: synapse loss is the major correlate of cognitive impairment. Ann Neurol 30:572-580. 
Trommsdorff M, Borg J, Margolis B, Herz J (1998) Interaction of cytosolic adaptor proteins with neuronal apolipoprotein $\mathrm{E}$ receptors and the amyloid precursor protein. J Biol Chem 273:33556-33560.

Ulery P, Beers J, Mikhailenko I, Tanzi R, Rebeck G, Hyman B, Strickland D (2000) Modulation of beta-amyloid precursor protein processing by the low density lipoprotein receptor-related protein (LRP). Evidence that LRP contributes to the pathogenesis of Alzheimer's disease. J Biol Chem 275:7410-7415

Umans L, Overbergh L, Serneels L, Tesseur I, Van Leuven F, Group EG (1999) Analysis of expression of genes involved in apolipoprotein E-based lipoprotein metabolism in pregnant mice deficient in the receptor-associated protein, the low density lipoprotein receptor, or apolipoprotein E. Biol Reprod 61:1216-1225.

Van Uden E, Veinbergs I, Mallory M, Orlando R, Masliah E (1999a) A novel role for receptor-associated protein in somatostatin modulation: implications for Alzheimer's disease. Neuroscience 88:687-700.

Van Uden E, Carlson G, St. George-Hyslop P, Westaway D, Orlando R, Mallory M, Rockenstein E, Masliah E (1999b) Aberrant Presenilin-1 expression downregulates LDL receptor-related protein (LRP): is LRP central to Alzheimer's disease pathogenesis? Mol Cell Neurosci 14:129-140.

Van Uden E, Sagara Y, Van Uden J, Orlando R, Mallory M, Rockenstein E, Masliah E (2000) A protective role of the low density lipoprotein receptor-related protein against amyloid $\beta$-protein toxicity. J Biol Chem 275:30525-30530.

Veinbergs I, Van Uden E, Mallory M, Alford M, McGiffert C, DeTeresa R, Orlando R, Masliah E (2001) Role of apolipoprotein E receptors in regulating the differential in vivo neurotrophic effects of apolipoprotein E. Exp Neurol 170:15-26.

Willnow T, Armstrong S, Hammer R, Herz J (1995) Functional expression of low density lipoprotein receptor-related protein is controlled by receptor-associated protein in vivo. Proc Natl Acad Sci USA 92:4537-4541.

Willnow T, Rohlmann A, Horton J, Otani H, Braun J, Hammer R, Herz J (1996) RAP, a specialized chaperone, prevents ligand-induced ER retention and degradation of LDL receptor-related endocytic receptors. EMBO J 15:2632-2639.

Yan SD, Chen X, Fu J, Chen M, Zhu H, Roher A, Slattery T, Zhao L Nagashima M, Morser J, Migheli A, Nawroth P, Stern D, Schmidt AM (1996) RAGE and amyloid-beta peptide neurotoxicity in Alzheimer's disease. Nature 382:685-691

Yang DS, Small DH, Seydel U, Smith JD, Hallmayer J, Gandy SE, Martins RN (1999) Apolipoprotein E promotes the binding and uptake of beta-amyloid into Chinese hamster ovary cells in an isoformspecific manner. Neuroscience 90:1217-1226.

Yazawa H, Yu ZX, Takeda, Le Y, Gong W, Ferrans VJ, Oppenheim JJ, Li CC, Wang JM (2001) Beta amyloid peptide (Abeta42) is internalized via the G-protein-coupled receptor FPRL1 and forms fibrillar aggregates in macrophages. FASEB J 15:2454-2462.

Zhan S, Beyreuther K, Schmitt H (1993) Quantitative assessment of the synaptophysin immuno-reactivity of the cortical neuropil in various neurodegenerative disorders with dementia. Dementia 4:66-74.

Zhuo M, Holtzman DM, Li Y, Osaka H, DeMaro J, Jacquin M, Bu G (2000) Role of tissue plasminogen activator receptor LRP in hippocampal long-term potentiation. J Neurosci 20:542-549. 